compulsory by the issue of statutory rules and orders. The preparation of standards for building materials and appliances now being carried out in support of the programme of house-building of the Ministries of Works and Health has already reached substantial proportions. Sir Percy concluded by emphasizing the importance of industrial standards, which provide for accurate and precise trade descriptions, methods of sampling and testing, and standards of performance, and of an independent body, set up and maintained by the national industry as a whole, with Government support but not under Government control; for the preparation of such standards. Progress will be most widespread and continuous if the policy of 'standardization by consent' is consistently pursued.

\section{Harvesting Machinery}

THE inaugural meeting of the 1944-45 session of the Institution of British Agricultural Engineers was held on October 17 at the Institution of Electrical Engineers under the chairmanship of Mr. C. I. C. Bosanquet, and Mr. Cornelius Davies read a paper on harvesting machinery. Mr. Davies, who has for many years been closely associated with the South-Eastern Agricultural College at Wye, Kent, traced the developments in methods of harvesting from the earliest times to the present day. His paper dealt not only with the harvesting of corn and potatoes but also with machinery for handling sugar beet, grass, silage, hops, vegetables and fruit. On the combine harvester Mr. Davies reminded the audience that this machine cuts and threshes the grain in one operation, and there is no period in the stook when final ripening can take place. Adequate drying facilities are necessary, and serious attention to grain storage is required. Nearly all combine owners are faced with a straw problem. $\mathrm{He}$ considers that to burn straw is evidence of bad husbandry. On some farms pick-up balers are used, but the cost of these is nearly as high as that of a combine; further, the use to which the baled straw can be put must be considered.

On the question of potato harvesting Mr. Davies discussed the relative merits of the spinner and the elevator lifter, and stressed the need that still exists for a really satisfactory potato harvester. In conclusion, Mr. Davies stated that in addition to the provision of more and better harvesting machines, there must be more skill in handling and greater care in maintaining and managing agricultural machinery. In the discussion which ensued, community ownership of expensive machines, the employment of contractors, and the development of simple and relatively inexpensive machines within the scope of private ownership on small farms were discussed.

\section{Cultural Co-operation}

UNDER the title "The Cultural Co-operation Program 1938-1943" (Washington: Govt. Printing Office. 15 cents), the U.S. Department of State has issued a report by $H$. Hanson describing the development since its inception of this programme for fostering international relations on a basis of mutual understanding and appreciation. The programme is conceived by the General Advisory Committee of the Division of Cultural Relations as a long-term one of continuing activities which should be as broad as intellectual and cultural activities themselves. A statement of policy issued by the Department on March 31, 1944, on the participation of the United
States in educational and cultural reconstruction in Europe, indicated the Department's intention of co-operating in the formation of a United Nations organization for educational and cultural reconstruction. This emergency programme to meet this need may consist of assistance in restocking essential educational facilities, especially books and scientific and other teaching aids; in the provision of opportunities for training carefully selected foreign students in American educational institutions; in re-establishing essential library facilities; and in the recovery and restoration to their rightful owners of scientific, artistic and archival materials looted by the Axis countries. The report includes some notes on professional and scientific relations, and on the various activities under the programme: these include travel and study grants, including student exchange, and the provision of technical experts for China; cultural centres, such as libraries, including the reference library opened by the Office of War Information in London in December 1942, which seeks by a careful loan service to place each new American book in the hands of selected people in the British Isles; cultural materials, such as books for libraries in the Western hemisphere, book translations, microflims for China and the Near East, science news letters and motion pictures and radio activities.

\section{Pitfalls of Positivism}

IN a most timely article entitled "Positivism" (Mind, July 1944), Prof. W. T. Stace throws great light on the doctrinaire character of the so-called logical positivists. After making a useful distinction between the 'meaning' of a word and the 'significance' of a sentence, he states the positivist principle as follows: "what makes a sentence significant is that some actual or possible observation can be deduced from it in conjunction with certain other premises, without being deducible from those other premises alone". He then makes his main point, that underlying this principle is another one more fundamental, which he calls the "Principle of Observable Kinds", and states as follows, "a sentence, to be significant, must assert or deny facts of a kind such that it is logically possible directly to observe some facts which are instances of that kind".

Prof. Stace points out that this principle is different from the positivist principle in that it introduces the notion of direct verification, whereas the positivist principle makes use of that of indirect verification. Further, this latter principle neither follows from the positivist principle nor is it self-evident. Nor again does it follow from the empiricist principle which states that all our simple ideas come from impressions, because this provides no guide as to how the former are to be combined to make significant sentences. In fact, Prof. Stace holds that there is no reason to think the principle true. It would follow that we should discard it and with it the positivist principle, if in fact this latter is based on it. But the proof which Prof. Stace gives that the two are related in this way is weak. Nevertheless, all those inclined to flirt with modern forms of positivism should study the article.

\section{Physical Society's Exhibition of Scientific Instru- ments and Apparatus}

THE Physical Society's long and almost continuous series of annual exhibitions of scientific instruments and apparatus was, of necessity, suspended during the War. Its resumption has recently been considered by the Council of the Society and by the Exhibition 
Committee, now under the chairmanship of Prof. G. I. Finch, who succeeds the late Mr. R. W. Paul, and it is proposed that the thirtieth exhibition (which was planned to take place in January 1940) shall be held in January 1946. It will take place in the Physics Department of the Imperial College, Imperial Institute Road, London, S.W.7, as on previous occasions, and will be on about the same scale as the exhibitions of the immediate pre-war years.

\section{Edward Emanuel Klein, F.R.S. (1844-1925)}

Dr. Edward Emanuer Klein, a pioneer in histological and bacteriological research, was born at Ersek in Hungary on October 31, 1844, and studied at Vienna, where he devoted himself to microseopic anatomy. In 1869 he came to England and served at first as histological assistant to Burdon Sanderson, but afterwards devoted himself entirely to bacteriology, of which he was the first representative in England. $\mathrm{He}$ was lecturer in histology and later of bacteriology at St. Bartholomew's Hospital Medical School, where Ronald Ross was one of his pupils. He was the author of "The Anatomy of the Lymphatic System" (1873-75), "At]as of Histology" with Mr. Lobb Smith (1879-80), "Elements of Histology" in collaboration with J. G. Edkins (1883), "Microorganisms and Disease" (1884), "Asiatic Cholera" (1884) and "Oriental Plague" (1906). He was also collaborator in a "Handbook for the Physiological Laboratory" (1873). He was elected a fellow of the Royal Society in 1875 . He died at Hove on February 9, 1925.

\section{The Night Sky in November}

NEw moon occurs on Nov, 15d. 22h. $29 \mathrm{~m}$. U.T. and full moon on Nov. $30 \mathrm{~d} .00 \mathrm{~h} .52 \mathrm{~m}$. The following conjunctions with the moon take place : Nov. $5 \mathrm{~d} .00 \mathrm{~h}$., Saturn $0.1^{\circ}$ N.; Nov. 10d. 18h., Jupiter $4^{\circ} \mathrm{S}$. ; Nov. 17d. 05h., Mercury $5^{\circ}$ S. ; Nov, 19d. 02h., Venus $3^{\circ} \mathrm{S}$. The following occultations of stars brighter than magnitude 6 take place: Nov. 2 d. $23 \mathrm{~h} .12 \cdot 0 \mathrm{~m}$., $i$ Tauri $(R)$; Nov. 3d. 22h. 06.1m., $20^{\circ} 1105 m(R)$; Nov. 8 d. 04 h. $19 \cdot 1 \mathrm{~m} ., 8$ Leon. $(R)$. The times refer to the latitude of Greenwich and $R$ refers to reappearance. Mercury sets 8 minutes after the sun on Nov. 1 and 52 minutes after the sun at the end of the month. Venus can be seen in the evenings, setting at $17 \mathrm{~h}$. $45 \mathrm{~m}$., $18 \mathrm{~h} .12 \mathrm{~m}$., and $18 \mathrm{~h} .18 \mathrm{~m}$, at the beginning, middle and end of the month respectively. Mars is too close to the sun for favourable observation. Jupiter rises at $2 \mathrm{~h}$. $19 \mathrm{~m}$. at the beginning of November and can be seen about midway between $\sigma$ and $u$ Leonis. At the end of the month the planet has moved into the constellation of Virgo and rises at 0h. $48 \mathrm{~m}$. Saturn, in the constellation of Gemini, sets at $12 \mathrm{~h} .09 \mathrm{~m} ., 1 \mathrm{~h} .12 \mathrm{~m}$. and $10 \mathrm{~h} .11 \mathrm{~m}$. at the beginning, middle and end of the month respectively. The times have been computed for the latitude of Greenwich and the effects of refraction are ignored in all cases. The Leonid meteors are due on November 13-14 but the shower has been very feeble for some years, and the same remark applies to the Andromedids, which were once fairly active during November 18-27.

\section{Anncuncements}

Ax a meeting of the Council of the Royal Society held on October 12, amendments were made to the statutes so as to make it clear that, since the passing of the Sex Disqualification (Removal) Act of 1919, there is no barrier to the admission of women into the fellowship of the Society. This decision was reached after the fellows of the Society had been consulted by postal vote and had approved the amendments ratified by the Council on that day.

The U.S. National Academy of Sciences, which serves as an off cial liaison agency between American scientific men and the Government, is to receive the Ordnance Distinguished Service Award of the U.S. Army. In a letter to Dr. Frank B. Jewett, president of the Academy, Maj.-General L. H. Campbell, jun., Chief of Ordnance, says : "It is my pleasure as Chief of Ordnance of the Army to tell you on behalf of the Ordnance Department that I am most grateful for the outstanding contributions the National Academy of Sciences has made to Ordnance progress in this war. The degree of that progress is best shown by the success of our fighting forces in all theaters of operations".

THE Lord President of the Council has appointed Sir Robert Robinson to be chairman of the Water Pollution Research Board of the Department of Scientific and Industrial Research, in succession to the late Mr. H. C. Whitehead.

Mr. A. V. WrLliamson, reader and head of the Department of Geography of the University of Leeds, has been elected to the newly instituted chair of geography, as from the beginning of the present session. The title of honorary reader in the history of economic theory in the University has been conferred on Mr. H. D. Dickinson, lecturer in economic history.

Str Samuel Courtauld has offered the University of Oxford $£ 2,000$ a year for seven years, for research into the relative eticiency of small- and large-scale business and allied problems of industrial structure and organization and kindred subjects, to be carried out under the direction of the warden and fellows of Nuifield College.

Fon the third successive year, a course of lectures on the application of statistical methods to industrial problems is being given by Dr. B. P. Dudding at the University of Sheffeld on Friday evenings, commencing October 20. These lectures are of a rather more advanced type than those given in earlier courses and although primarily intended for students of engineering are open without charge to suitably qualified men from industry.

The following scholarships, which are tenable for three or four years, according to the length of the course at the university selected, will be offered for competition by the Institution of Naval Architects in 1945: Martell Scholarship (£130 per annum); Trewent Scholarship ( $\$ 125$ per annum) in naval architecture; Denny Scholarship (£130 per annum) in marine engineering. The Denny Scholarship, age limit nineteen, is tenable for four years at the University of Glasgow only, with apprenticeship of five years. Entries for the Martell Scholarship close on January 15, and for the other Scholarships on May 31. The Wrought Light Alloys Development Association Research Scholarship ( $\$ 400$ per annum, tenable for two years) is to be awarded to graduates in applied science preferably less than thirty years of age on October 1, 1945 : entries close on July 31. Particulars can be obtained from the Secretary of the Institution of Naval Architects, 10 Upper Belgrave Street, London, S.W.I. 